Japan. J. Med. Sci. Biol., 19, 201-207, 1966

\title{
MOLECULAR SIZE OF CLOSTRIDIUM BOTULINUM TYPE E TOXIN IN “IZUSHI"
}

\author{
GENJI SAKAGUCHI, SUMIKo SAKAGUCHI \\ Department of Food Research, National Institute of Health, Tokyo \\ AND TAKASHI KARASHIMADA \\ Hokkaido Institute of Public Health, Sapporo, Japan
}

(Received: June 16th, 1966)

\begin{abstract}
Botulogenic "izushi" was prepared from flounders inoculated with spores of Clostridium botulinum type $\mathrm{E}$ by the method commonly practiced in the local areas. To determine the molecular size and the properties of the toxin in "izushi," the exudate of the "izushi" and the extract of the fish were subjected to gel filtration on Sephadex G-100 and ultracentrifugal separation in sucrose density gradient. Most of the toxin in "izushi" was proved to be in the form of precursor and to possess a large molecular size with a sedimentation constant $\left(\mathrm{S}_{20 . \mathrm{w}}\right)$ of about 11.5. The tryptic activation of the precursor in the "izushi" caused no appreciable reduction in the molecular size.
\end{abstract}

\section{INTRODUCTION}

We demonstrated that neither the precursor nor the trypsin-activated toxin of Clostridium botulinum type $\mathrm{E}$ obtained from the bacterial cells penetrated swollen gel of Sephadex G-200. The findings were ascribed to the large molecular weight of 200,000 or larger possessed by both the materials (Sakaguchi, Sakaguchi and Imai, 1964).

Gerwing, Dolman and Arnott (1962) reported a much smaller sedimentation constant $\left(\mathrm{S}_{20 . \mathrm{w}}\right)$ of 5.6 for a preparation of non-activated type $\mathrm{E}$ toxin; more recently, they reported an even smaller $\mathrm{S}_{20 . \mathrm{w}}$ of 1.7 for another preparation (Gerwing, Dolman, Reichmann and Bains, 1964). The discrepancy among their findings and ours must have resulted from the different materials and purification procedures.

Variable molecular sizes have also been reported for type A toxin. The crystalline toxin had a molecular weight of about 900,000 (Putnam, Lamanna and Sharp, 1948), which dissociated into fragments with a sedimentation constant of 7S (Wagman, 1963). By digesting the 7S toxin with pepsin, he obtained a dialyzable unit of $0.64 \mathrm{~S}$ (Wagman, 1963). The toxin appearing in the lymph of orally poisoned rats had a smaller sedimentation constant than the crystalline toxin; yet its sedimentation constant was about $7.9 \mathrm{~S}$ (Heckly, Hildebrand and Lamanna, 1960). Gerwing, Dolman and Bains (1965b) claimed that non-aggregated type A toxin had a molecular weight of 12,200. Recently, DasGupta, Boroff and Rothstein (1966) separated crystalline toxin into $\alpha$ and $\beta$ components with molecular weights of about 150,000 and 500,000 , respectively. The $\alpha$ component was

阪口玄二・阪口 澄子（国立予防衛生研究所食品衛生部）

唐島田 隆 (北海道立衛生研究所) 
highly toxic; while $\beta$ was non-toxic.

The important question of whether the large molecular form of botulinus toxins is normally produced by the organisms in foods or in cultures or appears only as an artifact of the purification procedures has not been clarified as yet. In the present study, attempts were made to determine the molecular size of type E toxin in "izushi," that is the commonest foodstuff involved in the outbreaks in Japan, by gel filtration on Sephadex G-100 and ultracentrifugal separation in sucrose density gradient.

\section{MATERIALS AND METHODS}

Preparation of the " $i z u s h i$ ": Fresh flounders were cut into pieces after the heads and viscellas were removed. About 250,000 spores of $C$. botulinum type E, strain Iwanai, were introduced by a syringe into each piece of fish. The fish pieces were soaked in water in a plastic container for a period of 3 days at 20 to $23 \mathrm{C}$, during which time water was changed twice a day. The soaked fish pieces, cooked rice, "koji" and cutup radish and carrot were placed into a plastic container. The content was compressed tightly and kept standing to allow fermentation at room temperature for 10 days. Afterwards, the container was kept under refrigeration.

Preparation of toxin materials: The turbid fluid with $\mathrm{pH} 4.28$ exudated during fermentation was taken. A portion of the fish meat was ground in a mortar with a pestle with an equal amount of $0.1 \mathrm{M}$ phosphate buffer, $\mathrm{pH}$ 6.0. The fish ground and the exudate were centrifuged at $12,000 \times g$ for $20 \mathrm{~min}$ and the clear supernatants were used as the toxin materials.

Gel filtration: A column of Sephadex G-100 $(2.5 \times 30 \mathrm{~cm})$ buffered with $0.05 \mathrm{M}$ acetate buffer, $\mathrm{pH} 6.0$, was loaded with $5.0 \mathrm{ml}$ of the exudate or the extract. Elution was carried out with the same buffer at room temperature. Protein content in each fraction was determined; toxicities of the combined fractions of every three tukes were determined before and after tryptic activation. The void volume was measured with a $0.2 \%$ Blue Dextran solution.

Ultracentrifugal separation in sucrose density gradient : Density gradient was prepared in cellulose tubes of $1.3 \times 5.1 \mathrm{~cm}$ by mixing two solutions of $0.05 \mathrm{M}$ phosphate buffer, $\mathrm{pH} 6.0$, containing sucrose in $20 \%$ and in $5 \%$, respectively, so that the final gradient of $20-5 \%$ would be obtained. Two-tenths $\mathrm{ml}$ each of the fish extract with and without tryptic activation together with a purified precursor solution containing protein at 1.34 $\mathrm{mg} / \mathrm{ml}$ and toxicities of $36,400 \mathrm{LD}_{50} / \mathrm{ml}$ before activation and $15,500,000 \mathrm{LD}_{50} / \mathrm{ml}$ after activation, that had been shown to have an $\mathrm{S}_{20 . \mathrm{w}}$ of approximately 11.5 , was placed on top of the gradient. The tubes were centrifuged in a Hitachi swinging bucket rotor model PRS 40 at $40,000 \mathrm{rpm}(105,000 \times g)$ for $5 \mathrm{hr}$.

The fractionation was accomplished by inserting a hypodermic needle into the tube's bottom and controling the outflow of solution by water pressure. Fractions of 20 drops (18 fractions from the $5-\mathrm{ml}$ sample) were collected. The toxic potency of each fraction was determined after tryptic activation in the case of the nonactivated exudate and the 11.5 $\mathrm{S}$ precursor.

The tryptic activation, toxin assay and protein determination were performed as described elsewhere (Sakaguchi et al., 1964). 


\section{RESULTS \\ Development of Toxin in "izushi"}

A piece of the fish after soaking in water contained toxic potencies of $320 \mathrm{LD}_{50} / \mathrm{g}$ and $64,000 \mathrm{LD}_{50} / \mathrm{g}$ before and after tryptic activation, respectively. On the 10th day after pickling, the exudate of the "izushi" contained $810 \mathrm{LD}_{50} / \mathrm{ml}$ and $29,000 \mathrm{LD}_{50} / \mathrm{ml}$ and the fish pieces $4,100 \mathrm{LD}_{50} / \mathrm{g}$ and $250,000 \mathrm{LD}_{50} / \mathrm{g}$ before and after activation, respectively. On the 77th day after the start of pickling, the extract from other pieces of fish still contained $6,400 \mathrm{LD}_{50} / \mathrm{g}$ and $210,000 \mathrm{LD}_{50} / \mathrm{g}$ before and after activatien.

\section{Gel Filtration on Sephadex G-100}

The elution patterns of the exudate and the fish extract are shown in Fig. 1. The majority of the toxic activities of both the samples were eluted in the void volume or in Fraction $\mathrm{A}$ being accompanied by a very small amount of protein. No significant

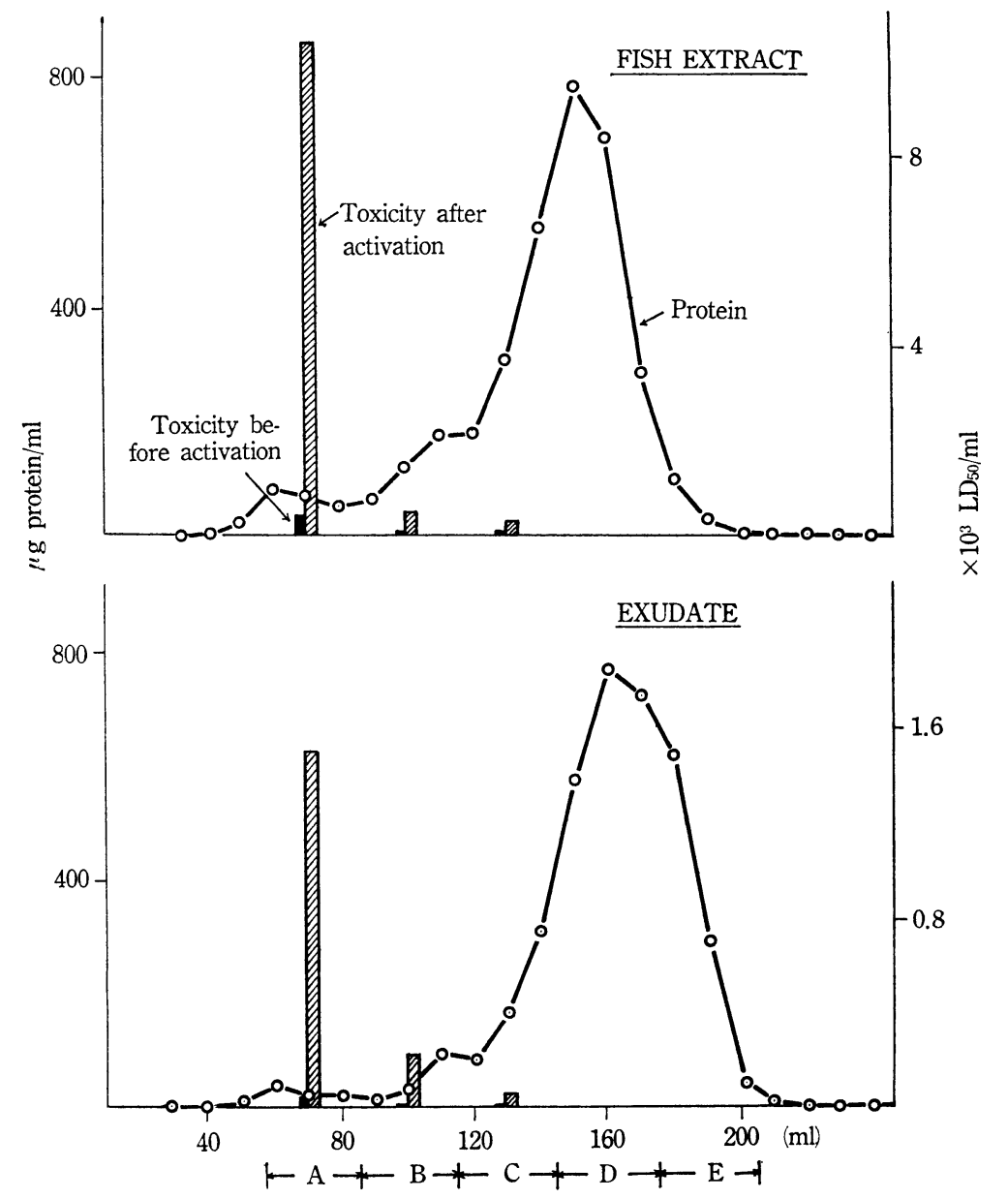

Fig. 1. Elution patterns of type $\mathrm{E}$ botulinus toxin in the exudate of "izushi" and in the extract of the fish from a column of Sephadex G-100 $(2.5 \times 30 \mathrm{~cm})$. 
amount of toxic activity was detected in the retarded fractions or in Fractions B, C, D and $\mathrm{E}$. The majority of the proteinous substances was eluted in the retarded fractions.

\section{Ultracentrifugal Separation in Sucrose Density Gradient}

The patterns of ultracentrifugal separation in sucrose density gradient of the fish extract before and after tryptic activation in comparison with the $11.5 \mathrm{~S}$ precursor are shown in Fig. 2. The toxic activities of the non-treated and the activated extract were sedimented to the same relative position; that of the purified precursor sedimented to a lesser extent. The position of the peak of toxic activity and that of protein were the same with the purified precursor; while most proteinous materials were separated from the toxic activity with the fish extract.

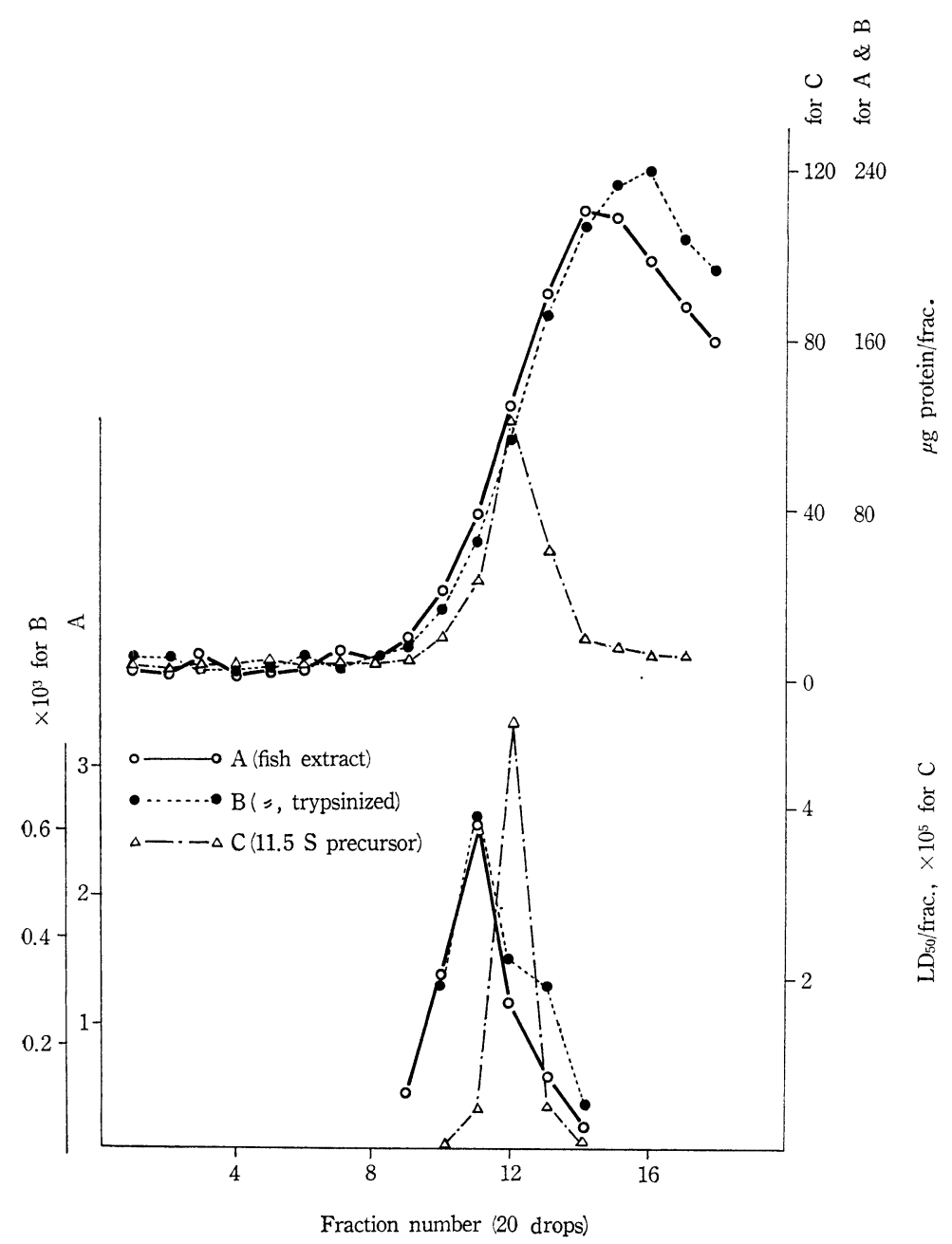

Fig. 2. Sedimentation patterns of type $\mathrm{E}$ botulinus toxin in the extract of the fish before and after tryptic activation and of the $11.5 \mathrm{~S}$ precursor in sucrose density gradient. 
Since the toxic potency of the extract was much lower than that of the $11.5 \mathrm{~S}$ precursor solution, the extract was concentrated by precipitation with ammonium sulfate at $50 \%$ saturation. The precipitate was dissolved in a small amount of $0.1 \mathrm{M}$ phosphate buffer, $\mathrm{pH}$ 6.0, and dialyzed against the same buffer. The potential toxicity of the dialyzate was 6 times higher than that of the original extract.

The same experiments were run with the concentrated fish extract before and after tryptic activation and also with the $11.5 \mathrm{~S}$ precursor as the control. As can be seen in Fig. 3, the toxic activities of the three materials were sedimented to the same relative position.

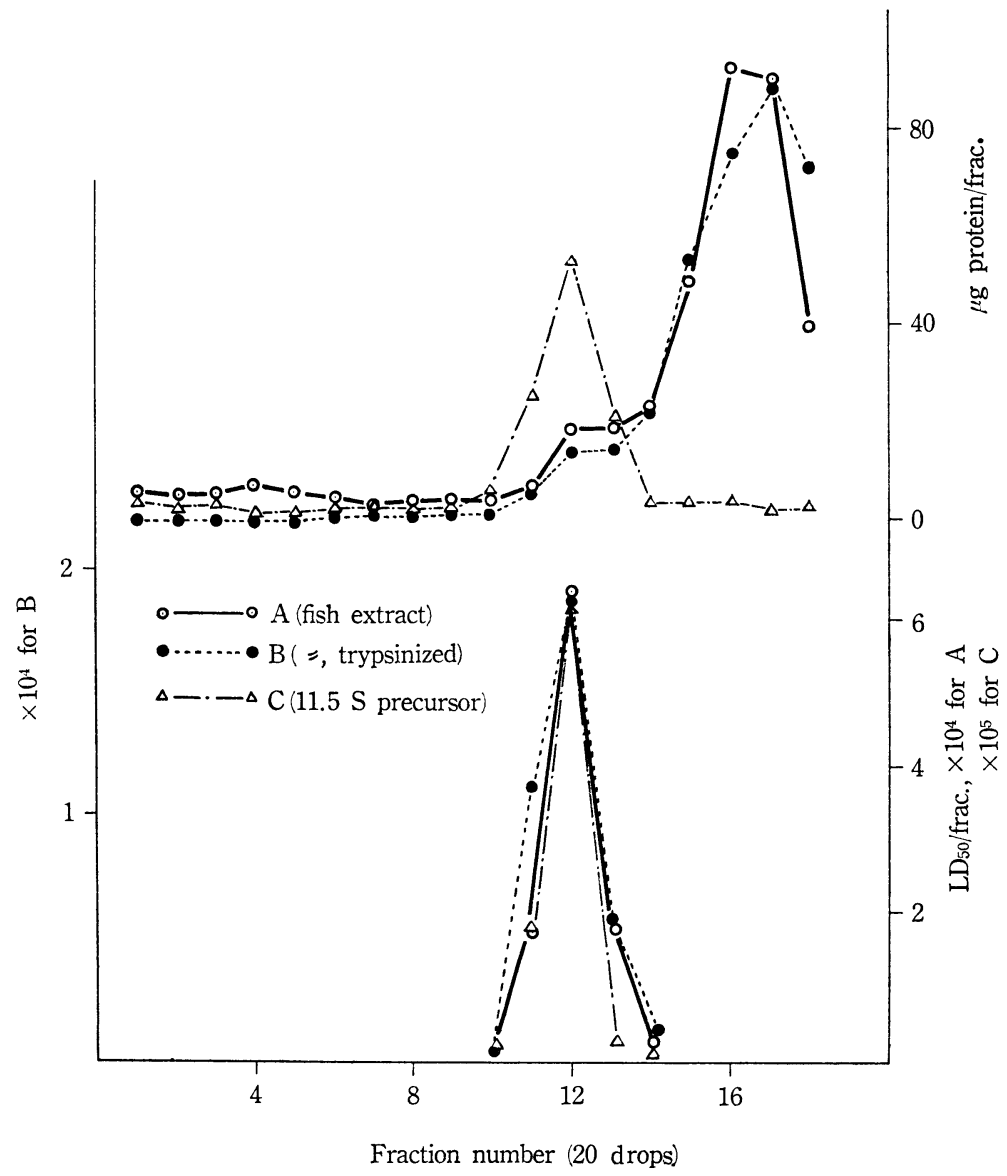

Fig. 3. Sedimentation patterns of the concentrated extract of the fish before and after tryptic activation and of the $11.5 \mathrm{~S}$ precursor in sucrose density gradient.

\section{DISCUSSION}

Gerwing et al. (1962, 1964) reported inconsistent molecular sizes of non-activated type $\mathrm{E}$ toxin, $\mathrm{S}_{20 . \mathrm{w}}=5.6$ and 1.7. They ascribed the discrepancy in their own work to molecular degradation and aggregation due to the use of ethanol and lyophilization in the 
former work. We reported that both the precursor and the trypsin-activated toxin possessed molecular weight larger than 200,000 (Sakaguchi et al., 1964). Gerwing, Dolman and Ko (1965a) claimed that our purification procedures for the precursor, especially the extraction of the toxin from bacterial cells with $1 \mathrm{M}$ acetate buffer and its repeated precipitation with solid ammonium sulfate, are conducive to the formation of molecular aggregates. However, they did not demonstrate aggregation of their small molecular-sized toxin by exposure to ethanol, ammonium sulfate or $1 \mathrm{M}$ acetate buffer. They also claimed that the true molecular weight of toxin should approximate the smallest figure.

Before attempting to obtain the smallest possible figure of the molecular size, one must answer a rather simple but fundamental question of what is the true molecular size of type $\mathrm{E}$ toxin normally produced by the organisms in foods or in cultures.

The results presented here clearly indicate that type $\mathrm{E}$ toxin appearing in "izushi" is for the most part in the form of the precursor and of a large molecular size. Since the toxin materials precipitated with ammonium sulfate had the same sedimentation pattern as the purified precursor with $\mathrm{S}_{20 . \mathrm{w}}$ of approximately 11.5 , the type $\mathrm{E}$ toxin in "izushi" may approximate this size.

Wagman and Bateman (1951, 1953) and Wagman (1954) stated that the molecular size of crystalline type A toxin is largely dependent upon the $\mathrm{pH}$ and ionic strength of the solvent. The $\mathrm{pH}$ of "izushi" usually lies between 4 and 5 (Kanzawa and Iida, 1957) and the present "izushi" had a $\mathrm{pH}$ of 4.28 , which was on the same level as the final $\mathrm{pH}$ of type $\mathrm{E}$ cultures of our routine use (Sakaguchi et al,, 1964). On the other hand, Gerwing and her associates utilized dialyzing culture with daily changes of culture medium outside the casing (Gerwing, Dolman and Arnott, 1961). The method may have provided a fairly constant $\mathrm{pH}$ at or above 7.0, thus providing more chances for molecular dissociation or enzymatic degradation with the proteolytic enzyme produced by the toxigenic phase (Skulberg, 1964) or by the proteolytic mutant phase (Dolman, 1957).

At any rate, it may be true that the victims in this country ate principally the large molecular sized precursor in "izushi." The present investigation also demonstrated that the precursor in "izushi" was not appreciably reduced in size when acted upon by trypsin at $\mathrm{pH}$ 6.0. If tryptic activation takes place at the upper part of the duodenum where the $\mathrm{pH}$ may be still acidic, the activated toxin should be of a large molecular size. At the lower part of the intestine where the $\mathrm{pH}$ is higher, the toxin may undergo dissociation and detoxification rather slowly by trypsin, chymotrypsin (Sakaguchi and Sakaguchi, to be published) and possibly other proteolytic enzymes.

The present data seem to support the use of the precursor of a large molecular size in the studies on the mechanism of tryptic activation of type $\mathrm{E}$ toxin.

This investigation was supported in part by U. S. Public Health Service Research Grant EF-00361 from the Division of Environmental Engineering and Food Protection.

\section{REFERENCES}

Dasgupta, B. R., Boroff, D. A. And Rothstein, E. (1966) : Chromatographic fractionation of the crystalline toxin of Clostridium botulinum type A. Biochem. Biophys. Res. Commun., 22, 750-756.

Dolman, C. E. (1957) : Recent observations on type E botulism. Can. J. Publ. Health, 48, 187-198. 
Gerwing, J., Dolman, C. E. ANd ARnott, D. (1961): Purification and activation of Clostridium botulinum type $\mathrm{E}$ toxin. J. Bacteriol., 81, 819-822.

Gerwing, J., Dolman, C. E. AND ARnotT, D. (1962) : Activation phenomenon of Clostridium botulinum type $\mathrm{E}$ toxin. J. Bacteriol., 84, 302-306.

Gerwing, J., Dolman, C. E., Reichmann, M. E. And Bains, H. S. (1964): Purification and molecular weight determination of Clostridium botulinum type $\mathrm{E}$ toxin. J. Bacteriol., $88,216-219$.

Gerwing, J., Dolman, C. E. AND Ko, A. (1965a): Mechanism of tryptic activation of Clostridium botulinum type E toxin. J. Bacteriol., 89, 1,176-1,179.

Gerwing, J., Dolman, C. E. AND Bains, H. S. (1965b): Isolation and characterization of a toxic moiety of low molecular weight from Clostridium botulinum type A. J. Bacteriol., 89, $1,383-1,386$.

Heckly, R. J., Hildebrand, G. J. and Lamanna, C. (1960): On the size of the toxic particle passing the intestinal barrier in botulism. J. Exptl. Med., 111, 745-759.

KANZAWA, K. AND IIDA, H. (1957) : Studies on prevention of toxin production by Clostridium botulinum type E in "izushi," Report 2. Rep. Hokkaido Inst. Publ. Health, 8, 33-38. (Text in Japanese)

Putnam, F. W., Lamanna, C. ANd Sharp, D. G. (1948): Physicochemical properties of crystalline Clostridium botulinum type A toxin. J. Biol. Chem., 176, 401-412.

SAKAGUCHI, G., SAKAGUCHI, S. AND IMAI, N. (1964): Comparative gel filtration of toxin precursor and trypsin-activated toxin of Clostridium botulinum type E. J. Bacteriol., 87, 401-407.

SkUlbERG, A. (1964): Studies on the formation of toxin by Clostridium botulinum. A/S Kaare Grytting, Orkanger, Norway.

Wagman, J. AND BAteman, J. B. (1951): The behavior of the botulinus toxins in the ultracentrifuge. Arch. Biochem. Biophys., 31, 424-430.

Wagman, J. And Bateman, J. B. (1953): Botulinum type A toxin: Properties of a toxic dissociation product. Arch. Biochem. Biophys., 45, 375-383.

WAGMAN, J. (1954): Isolation and sedimentation study of low molecular weight forms of type A botulinus toxin. Arch. Biochem. Biophys., 50, 104-112.

WAGMAN, J. (1963) : Low molecular weight forms of type A botulinus toxin. II. Action of pepsin on intact and dissociated toxin. Arch. Biochem. Biophys., 100, 414-421. 